\title{
ANALYZING THE EFFICIENT MARKET HYPOTHESIS WITH THE FOURIER UNIT ROOT TESTS: EVIDENCE FROM G-20 COUNTRIES
}

\author{
Fatih Burak Gümüș ${ }^{a}$, Feyyaz Zeren ${ }^{b, *}$ \\ ${ }^{a}$ Faculty of Management, Sakarya University, Sakarya, Turkey \\ ${ }^{b}$ Faculty of Economics and Administrative Sciences, Namık Kemal University, Tekirdağ, Turkey
}

\begin{abstract}
The efficient market hypothesis is one of most important theories in finance and one of the most important research areas for both developed and developing stock markets. In this study, the random-walk hypothesis is tested for the main stock markets of the G-20 countries. The linearity of the series is determined in the first stage. In this context, 16 of 17 markets have a linear structure; therefore, the Fourier ADF unit root test that uses trigonometric functions in order to capture deviations greater than the average of the dependent variable and takes into account multiple structural breaks, is applied to these series. Furthermore, the Fourier KSS unit root test that has the same functions as the Fourier ADF unit root test is used for the Japanese stock market, being the only one market with a non-linear structure. As the result of these analyses, while the markets of the nine countries are observed as effective in the weak form, this hypothesis is not valid for the remaining eight countries. While the prediction of the future price of all of these nine markets will be impossible through a technical analysis, investors in the remaining eight markets can provide returns by carrying out the same analysis.
\end{abstract}

Keywords: efficient market hypothesis, random walk, international markets, linearity test, Fourier unit root tests

JEL Classification: G14, G15

\section{INTRODUCTION}

The Efficient Market Hypothesis was developed by E. F. Fama (1970), related to the effects of data obtained in relation with the securities on their prices. As there are previous studies supporting the hypothesis

\footnotetext{
* Correspondence to: F. Zeren, Faculty of Economics and Administrative Sciences, Namık Kemal University, 59100, Tekirdağ, Turkey, e-mail: feyyazzeren@hotmail.com
}

developed by E. F. Fama, he was the first to present the issue systematically. E. F. Fama associated competitive economic theory with an information-based perspective to the prices of securities (Ball, 2009, 26). Thousands of academic studies have been conducted related to the efficient market hypothesis until today. The efficiency concept in the efficient market hypothesis refers to informative efficiency and one of the most important assumptions of the hypothesis is that no investor may have extraordinary returns using 
any information (Bayraktar, 2012, 38). According to the hypothesis, since the price of securities completely reflects all the existing information in the market, no investor would obtain differentiated returns. The core idea of the Efficient Market Hypothesis is that if information is not blocked and if it is rapidly reflected by stock prices, then tomorrow's price changes would reflect tomorrow's news and would be independent of today's price changes. In addition, if news may be estimated, then price changes may not be estimated and they are incidental. When prices completely reflect information, investors who may not access information and purchase a diversified portfolio from the market may also obtain returns as much as by specialists (Malkiel, 2003, 59). That is to say the portfolios, examined for a long time and created by specialists, may also provide returns to an investor who may not access information in a timely manner as much as they may to other investors. Today's markets mostly reflect this reality, too. Even if income such as rental income from investment to house, income from an interest and profit shares in capital, income through trade differ from each other in the short term, then the markets balance each other in the course of time and come to a position to provide income to each other in not a long time. This is realized by making investors invest more in areas providing higher profits. If an excessive profit in the market is in question, then there will be new accessions to the market, which will either eliminate or reduce profitability (Ball, 2009, 5).

According to the Efficient Market Hypothesis, the more local and foreign investors find an opportunity to access the market the more information is reflected in the current price (Kawakatsu \& Morey, 1999, 386). An increase in the number of foreign investors will contribute both to the HEM market efficiency and to the fair determining of the price.

It is suggested that the information related to stock prices through the Efficient Market Hypothesis has an impact on the price at three different degrees, which results in three different markets.

According to the categorization, the first market is the weak efficient market. All the information related to shares is reflected in the stock prices in this market. Thus, since the stock prices reflect all the information, it is senseless to estimate the future prices of these shares, because, according to this hypothesis, the prices of the shares traded in the market occur randomly. Therefore, it is very difficult to estimate the prices that have accidently occurred through scientific methods. The term Random-Walk Hypothesis is sourced from here. According to this hypothesis, it is not possible to forecast the future price of shares using historical share prices (Fama, 1970). It may be formulated as follows:

$$
Y_{t}=Y_{t-1}+u_{t}
$$

where: $Y_{t}$ represents a future share price, $Y_{t-1}$ represents historical share prices, $u_{t}$ represents the stochastic error term. The model has a zero mean and constant covariance. Moreover, there is no autocorrelation problem in this model.

If the weak efficient market conditions are in question, then stock prices are characterized by the unit root (Lee, C. C., Lee, J., \& Lee, C. 2010, 49). The weak efficient market hypothesis is intended for testing the existence of the unit root (Çevik \& Yalçın, 2003, 21). Successive stock prices are independent of each other under these market conditions.

The second type of the market is the semi-strong efficient market. All information open to the public is reflected in the stock prices in that market. However, information not open to the public and referred to as in-company information is not reflected in prices.

In the categorization, the third one is the strong efficient market hypothesis. All information, including both information open to the public and private information usually not shared, is reflected in the stock prices in this market type (Timmermann \& Granger, 2004)

There are many studies worldwide revealing that stock prices follow a random walk. Such studies have covered the period from the 1970s to today. M. C. Jensen (1978) claimed he had carried out a study which other econometric works having stronger pieces of evidence consistent with the efficient market hypothesis were not able to. This has been the dominant paradigm in the finance sector for years. Besides this, there are studies revealing that stock prices in many markets in 
the world do not follow the random walk differently from the efficient market hypothesis and that stock prices may be estimated on a certain basis. The significant majority of studies inconsistent with such type of the Efficient Market Hypothesis were being carried out during the 1980s and the 1990s (Sewell, 2011, 7). One of the important and striking objections against the Efficient Market Hypothesis was the one pursued by S. J. Grossman and J. E. Stiglitz. According to these authors (1980), the existence of an excellent efficient market regarding information is not possible due to reasons such as a higher cost of information, never perfectly reflecting information by prices. That is to say, prices will never be fully efficient. The majority of many financial econometricians suggest that stock prices may not be estimated with respect to dividends, the price-return ratio and past returns (Malkiel, 2005, 2). This leads us to the efficient market hypothesis being inconsistent with certain stock-exchanges in certain intervals of time. For example, as the efficient market hypothesis refuses possible higher income returns, shares with a lower price/income value tend to have a higher price/return ratio in the future, according to the price-return hypothesis (Basu, 1977, 680). Thanks to this, price-return theory asserts that it is possible to estimate shares providing a higher performance. Many studies have been carried out to prove this hypothesis in the academic environment. J. Fox (2009) stated that since investors and regulators strongly believed in that prices reflected all information according to the efficient market hypothesis, they did not examine in detail whether securities had correct values or not, which led to price bubbles and financial crises.

The results that differed from each other have been obtained in connection with the efficient market hypothesis in the world stock markets. As one meets randomly stepping in stock prices in certain studies, some studies provided us with findings saying that price estimations for the future by using the data of the past would lead to higher returns.

So, why have the results, inconsistent with the efficient market hypothesis, intensively been obtained in many academic works, especially recently? One of the most important reasons is that the academic works discussed have been carried out according to the methods working in different periods, under different assumptions and in countries having different characteristics and being at different development levels.

This work is a study of whether stock prices on the stock-exchanges of the 17 G-20 countries where different periods were discussed followed a random walk or not. Firstly, the studies carried out for this purpose until now have been put in an order providing the method used, time intervals and the results obtained. Secondly, the work discusses which country's stock-exchange data are used in which time interval, the methodology showing which methods and tests are implemented and the data section is provided. Thirdly, the works are submitted in the tables and figures, and the results that may be obtained from the work are provided in the final section.

\section{LITERATURE REVIEW}

Numerous academic works can be found in the literature on testing the hypothesis of efficient markets. However, this chapter addresses some of these academic works in the literature on testing the efficiency of the market hypothesis in stock markets using either the time series or panel unit root test.

The academic work conducted by M. Hasanov and C. Omay (2007) analysed the efficiency of the stock markets in Bulgaria, the Czech Republic, China, Hungary, Poland, Romania, Russia and Slovakia, using the nonlinear unit root test. In their work, they identified the unit root in price series in the stock markets of Bulgaria, Slovakia, Hungary and the Czech Republic and concluded that these markets were efficient in the weak form.

Another academic work conducted by T. Choudhry (1997) analysed six Latin American states, namely Argentina, Brazil, Chili, Colombia, México and Venezuela, using the ADF unit root test for the period from January 1989 to December 1993, and deduced that these markets were efficient.

In his study, M. R. Borges (2008) tested market efficiency in the stock markets of France, Germany, 
the UK, Greece, Portugal and Spain, for the period from January 1993 to December 2007. He applied the correlation test, the run test, the ADF test and the LoMackinley multivariate ratio test on the basis of daily and weekly data, thus revealing that weekly costs and returns were consistent with random walk theory.

K. Chaudhuri and Y. Wu (2003) analysed stock markets in 17 developed countries using the ADF and PP unit root tests for the period from January 1985 to February 1997, on the basis of weekly data, and deduced that these markets were efficient. They also analysed the same stock markets using the SURADF panel unit root test for the period from January 1985 to April 2002, on the basis of weekly data, and reached a conclusion that these markets were not efficient.

Another academic study conducted by K. P. Narayan and A. Prasad (2007) analysed the stock exchange markets of 17 countries using three different panel unit root tests, namely the LLC, the SURADF and the MADF tests, for the period from January 1988 to March 2003, and revealed that these markets were consistent with the efficient market hypothesis.

K. P. Narayan (2008) analysed the stock markets of the G7 countries using one and two break panel LM unit root test on the basis of weekly data for the period from January 1975 to April 2003 and identified inefficient market findings. In another study of his, using the ADF unit root test on the basis of weekly data, K. P. Narayan deduced that the stock prices in Australia and New Zeeland were consistent with the efficient market hypothesis.

K. P. Narayan and R. Smith (2007) tested random walk theory by using different unit root tests in the G7 countries on the basis of weekly stock market data, taking different time sequence for each country, and they revealed the random-walk hypothesis in these markets.

Another study conducted by H. H. Lean and R. Smyth (2007) tested the efficiency of the share market in 8 Asian countries using one and two break LM panel unit root test for the period from January 1998 to June 2005, and deduced that these markets were inefficient. According to this study, prices in stock markets were consistent with the random-walk hypothesis.
In their work, H. Kawakatsu and M. Morey (1999) analysed the stock markets of 16 developing countries using the DF-GLS and the KPSS unit root tests for the period from January 1976 to December 1997 and deduced that these markets were inefficient.

C. C. Lee et al. (2010) applied the KPSS unit root test to the stock markets of various countries. As a result of their study, the stock shares of 32 developed and 26 developing countries were of a stationary structure. The results were inconsistent with the efficient market hypothesis and a profitable arbitrage potential existed.

A. Abraham, F. Seyyed and S. Alsakran (2002) tested the random-walk hypothesis in Kuwait, Bahrain and Saudi Arabia using the variance ratio on the basis of weekly index data for the period from October 1992 to December 1998. According to this study, the market efficiency in these three countries was in the weak form and while the results of Saudi Arabia and Bahrain were consistent with the random-walk hypothesis, the results of Kuwait were inconsistent with the random-walk hypothesis. In another study, $\mathrm{K}$. Hamid, M. T. Suleman, S. Z. A. Shah and R. S. I. Akash (2010) examined 14 Asia Pacific countries in the study using the ADF test and concluded that the randomwalk hypothesis was invalid.

In another study, J. C. Dias, L. Lopes, V. Martins and J. M. Benzinho (2002) tested the efficiency of the markets in Portugal and Spain using the ADF unit root test and the variance ratio test. The study resulted in both markets being consistent with the random-walk hypothesis. In another study that examined market efficiency by applying the variance ratio test, A. Haque, H. C. Liu and F. U. Nisa (2011) tested Pakistan's stock markets and concluded that the random-walk hypothesis was invalid for this stock market.

G. Smith and H. J. Ryoo (2003) tested the random-walk hypothesis in the stock markets of Greece, Turkey, Hungary, Portugal and Poland using the multivariate ratio test for the period from April 1991 to Agust 1998 on the basis of weekly data and 385 observations. Except for Istanbul, the results of stock exchanges in the other 4 countries were inconsistent with the hypothesis. As a result of high turnover in the 1990s, the results for Istanbul Stock Exchange were consistent with the random-walk hypothesis. 
A. C. Worthington and H. Higgs (2004) applied the correlation test, the run test, the ADF test, the KPSS unit root test and the multivariate test to 20 European states for the period from August 1995 to May 2013 on the basis of daily returns. As a result of the study, the only one stock exchange that was consistent with the random-walk hypothesis was the stock exchange of Hungary, which was efficient in the weak form. Amongst developed countries, Germany, Ireland, Portugal, Sweden and the UK showed findings consistent with the hypothesis.

As seen in the foregoing literature, in order to test the consistency of stock quotations in markets by means of the random-walk hypothesis, the variance ratio test, autocorrelation and the linear or nonlinear unit root tests are used.

In contrast to other studies, the series in this study are not classified according to the assumptions of their being either linear or nonlinear. Their being linear or nonlinear is determined according to the linearity test developed by D. I. Harvey, S. J. Leybourne and B. Xiao (2008). Thereafter, in order to test the efficient market hypothesis, the Fourier ADF test is applied to the linear series and the Fourier KSS unit root test is applied to the nonlinear ones. It is our aim to reach more reliable results through these new tests.

\section{METHODOLOGY AND DATA}

The Fourier series is an expansion of the periodic $y_{t}$ function as the sum form of cosines and sinuses. The Fourier ADF and the Fourier KSS tests developed by D. K. Christopoulos and M. A. León-Ledesma (2010) use trigonometric functions in order to capture deviations greater than the average of the dependent variable (Zhou \& Kutan, 2014). The advantage of this test is its taking into account the plurality of temporary smooth structural breaks (Yılancı \& Eriş, 2013). The econometric model of this test can be explained as follows:

$$
y_{t}=\lambda_{0}+\lambda_{1} \sin \left(\frac{2 \pi k t}{T}\right)+\lambda_{2} \cos \left(\frac{2 \pi k t}{T}\right)+v_{t}
$$

where, $T, \lambda_{1}$ and $\lambda_{2^{\prime}} \pi$ and $k$ represent the sample size, the Fourier coefficients, the number of 3.1416 and the used frequency value in order to find the optimal value minimizing the sum of the least square residuals, respectively.

In order to apply this test, first, $k$ representing the sum of the least square residuals must be determined. After determining a suitable frequency $(k)$, the significance of the F-statistics obtained from this model will be checked according to the critical values stated in $\mathrm{R}$. Becker, W. Enders and J. Lee (2004). In the last stage, the residual series of the model with the determined $k$ value is created and the conventional ADF or the KSS unit root tests is applied to this residual series depending on the linearity structure. In this way, the Fourier ADF and the Fourier KSS test can be made (Anoruo \& Nwala, 2014). According to these tests, while the zero hypothesis represents the existence of the unit root, the alternative hypothesis claims the stationarity of the series (Christopoulos \& León-Ledesma, 2010).

The feature of one series in the long term can be revealed by determining how the value of a variable in the previous period affects the following period. Although many methods have been developed, the most commonly used ones are the unit root tests (Tarl, 2012, 386). If a series has a unit root, the random-walk hypothesis is said to be valid for this series. When series are stationary, the efficient market hypothesis will not be valid for those stock prices (Gujarati, 2011, 718).

The focal point of our study is examining whether the stock markets of G20 countries with data from different periods are weak-effective. In weak-effective markets, the prices of stock prices are random; therefore, stock prices allegedly determined at a random or unpredictable manner will be tested in this study whether stock prices actually seems to be moving in this way.

In our monthly data used study, the stock market consists of various start dates since we could not reach equally spaced data, and the Harvey linearity test results are listed in Table 1 . All the data are obtained from the www.uk.finance.yahoo.com website. Moreover, although Saudi Arabia and South Africa are 
among the G20 countries, they are excluded from the analysis since the fundamental market data for these countries are not obtained.

\section{EMPIRICAL FINDINGS}

In the time series, the analysis has been performed by considering the series to be either linear or non-linear in almost all studies in the literature. However, testing the linearity of the series by conducting various analyses will be a more accurate approach. In this respect, the linearity test developed by Harvey et al. (2008) will serve a purpose. The results of this test are shown in Table 1. According to the test, the series are linear if the W-lam values are smaller than the critical values, on the one hand, and the series are non-linear if it is the other way round. By the results, 16 out of the 17 examined countries have a linear structure and the
Japanese stock market is in the non-linear form. The reason why so many countries are in the linear form lies in their using data monthly. Moreover, daily data is used in a similar study made by F. Zeren and A. M. Konuk (2013) via the Harvey linearity test (2008), and the series tend to be rather non-linear with more observations.

After determining the linearity of the series, the weakform efficiency of the stock markets will be investigated by means of the unit root tests. In this study, the Fourier unit root test (the Fourier ADF) based on the linear unit root models is used for country stock markets in the linear form, the Fourier unit root test (the Fourier KSS) based on the non-linear unit root models is used for country stock markets in the non-linear form. According to the Fourier ADF unit root results in Table 2, the Efficient Market Hypothesis is valid for Germany, the USA, Argentina, Australia, France, India, the UK and Italy, i.e. for the eight countries in

Table 1 Harvey Linearity Test Results

\begin{tabular}{|c|c|c|c|c|c|c|}
\hline \multirow{2}{*}{ Stock-Market } & \multirow{2}{*}{ Starting Date } & \multirow{2}{*}{ W-Lam } & \multicolumn{3}{|c|}{ Critical Values } & \multirow{2}{*}{ Results } \\
\hline & & & $\% 10$ & $\% 5$ & $\% 1$ & \\
\hline Germany & Jan-1991 & $0.55^{*}$ & 4.64 & 4.68 & 4.76 & Linear \\
\hline USA & Mar-1950 & $2.67^{*}$ & 26.92 & 27.54 & 28.67 & Linear \\
\hline Argentina & Oct-1996 & $12.81 *$ & 17.08 & 17.34 & 17.80 & Linear \\
\hline Australia & Jan-2001 & $1.57^{*}$ & 2.49 & 2.51 & 2.54 & Linear \\
\hline Brazil & Apr-1993 & $0.88 *$ & 14.52 & 14.68 & 14.97 & Linear \\
\hline China & Dec-1990 & $3.76 *$ & 24.60 & 24.72 & 24.94 & Linear \\
\hline Indonesia & Jul-1997 & $0.65^{*}$ & 2.65 & 2.70 & 2.81 & Linear \\
\hline France & Mar-1990 & $1.80^{*}$ & 4.46 & 4.49 & 4.53 & Linear \\
\hline South Korea & Jul-1997 & $0.53^{*}$ & 6.66 & 6.73 & 6.88 & Linear \\
\hline India & Jul-1997 & $0.36^{*}$ & 9.15 & 9.47 & 10.05 & Linear \\
\hline UK & Apr-1984 & $7.08^{*}$ & 15.62 & 15.78 & 16.05 & Linear \\
\hline Italy & Jan-1998 & $6.71 *$ & 8.22 & 8.30 & 8.45 & Linear \\
\hline Japan & Jan-1984 & 6.15 & 5.66 & 5.70 & 5.77 & Non-Linear \\
\hline Canada & Apr-1984 & $12.50 *$ & 19.63 & 19.90 & 20.38 & Linear \\
\hline Mexico & Nov-1991 & $1.50^{*}$ & 4.79 & 4.91 & 5.11 & Linear \\
\hline Russia & Sep-1995 & $6.16^{*}$ & 15.46 & 15.58 & 15.78 & Linear \\
\hline Turkey & Feb-1986 & $8.27^{*}$ & 13.07 & 13.67 & 14.83 & Linear \\
\hline
\end{tabular}

Note: *Represents linearity at the $1 \%$ significance level. 
Table 2 Fourier ADF Unit Root Test Results

\begin{tabular}{l|rrrr}
\hline Country & Min SSR & k & FADF & F(k) \\
\hline Cermany & 17.15 & 1 & -1.87 & 443.49 \\
USA & 60.26 & 1 & -2.34 & 7752.17 \\
Argentina & 17.64 & 4 & -2.59 & 530.28 \\
Australia & 2.84 & 3 & -1.75 & 83.24 \\
Brazil & 97.90 & 1 & $-8.02^{* * *}$ & 466.53 \\
China & 39.68 & 1 & $-3.41^{*}$ & 350.04 \\
Indonesia & 8.64 & 3 & $-3.34^{*}$ & 1499.05 \\
France & 12.78 & 4 & -2.10 & 333.27 \\
South Korea & 8.36 & 3 & $-3.23^{*}$ & 483.17 \\
India & 8.21 & 4 & -2.46 & 1000.90 \\
UK & 8.34 & 1 & -2.60 & 1673.38 \\
Italy & 8.17 & 1 & -2.35 & 148.30 \\
Japan & 6.48 & 3 & $-3.74^{* *}$ & 2574.45 \\
Canada & 9.50 & 2 & $-3.21^{*}$ & 3877.00 \\
Mexico & 42.13 & 4 & $-3.37^{*}$ & 506.16 \\
Russia & 57.69 & 2 & $-3.82^{* *}$ & 10776.06 \\
\hline
\end{tabular}

Note: $* * *, * * *$ represent the $10 \%, 5 \%$ and $1 \%$ significance levels, respectively. In the model with the constant and the trend, the critical values for the F statistics are $4.162,4.972$ and 6.873 for 100 observations and the $10 \%, 5 \%$ and $1 \%$ significance levels, respectively. These values are 3.928 , 4.669 and 6.315 for 500 observations. Suitable critical values for observations between 100 and 500 are chosen whether 100 or 500 accordance to closeness. (These critical values are obtained from: Becker et al, 2004, 389).

Source: Authors

total. Again, according to these results, this hypothesis is not valid for Brazil, China, Indonesia, South Korea, Canada, Mexico, Russia and Turkey, whose series are stationary. Moreover, Min SSR represents the sum of the least residuals square in the situation when $\mathrm{k}$ is the optimal value, and $\mathrm{F}(\mathrm{k})$ represents the F statistics.

Table 3 accounts for the Fourier KSS unit root test results. The series is observed with the unit root and thus, the Efficient Market Hypothesis is valid for the
Japanese stock market.

In Figure 1, the comparison of the series in the form after a logarithmic transformation and the transformed forms of these series according to the Fourier functions are given. Here, an adjustment in order to capture changes greater than the dependent variable average and to see how the structural breaks of the Fourier functions are taken into consideration can clearly be seen.

Table 3 Fourier KSS Unit Root Test Results

\begin{tabular}{l|rlll}
\hline Country & Min SSR & k & FKSS & F(k) \\
\hline Japan & 21.46 & 5 & -1.99 & 232.53 \\
\hline
\end{tabular}

Note: The asymptotic critical values for the KSS test statistics constant and trend model are $-3.93,-3.40$ and -3.13 for $1 \%, 5 \%$ and $10 \%$, respectively. (These critical values are obtained from: Kapetanios, Shin \& Snell, 2003, 364).

Source: Authors 

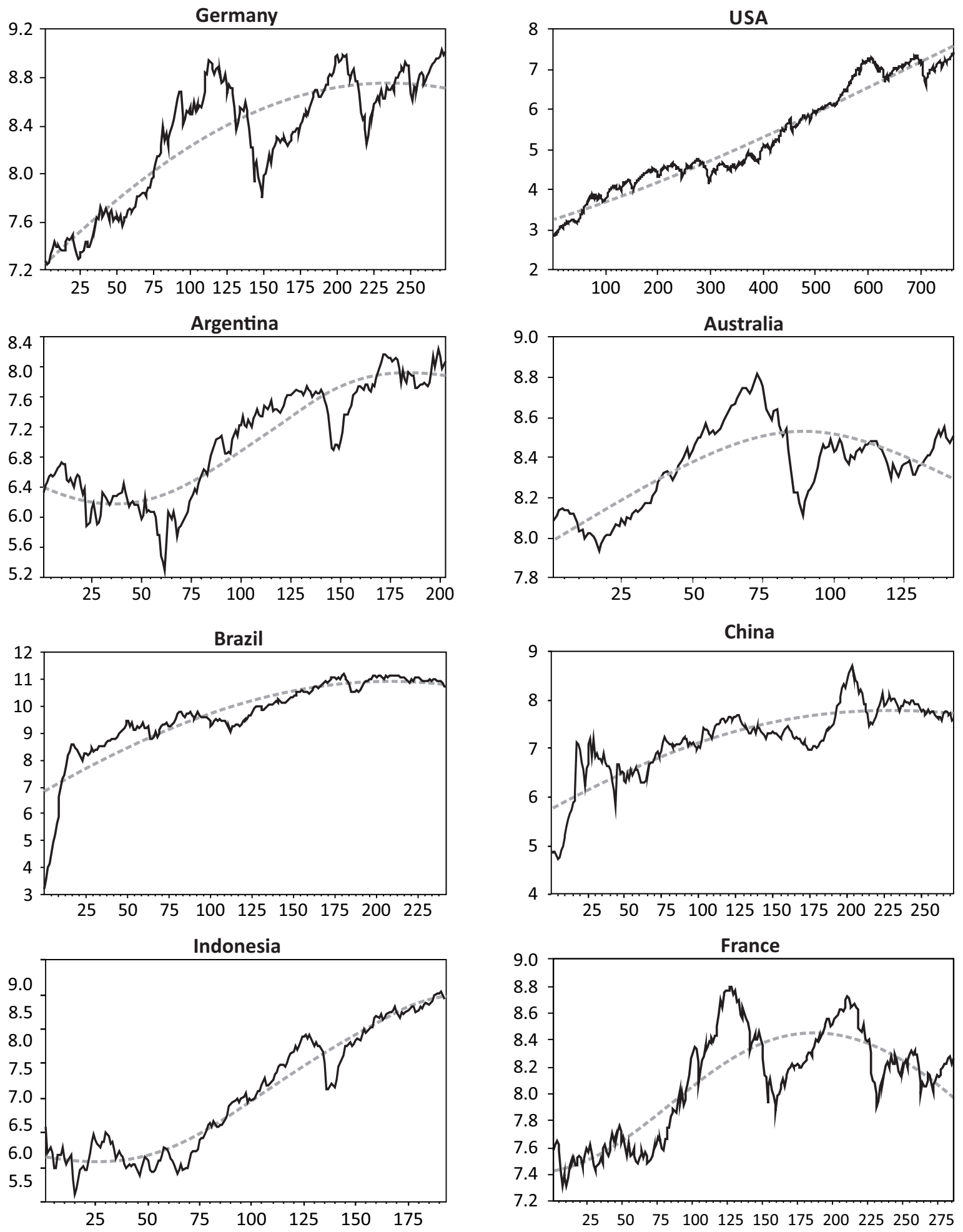

Figure 1 Stock Market Index of G-20 Countries and Related Fourier Functions 

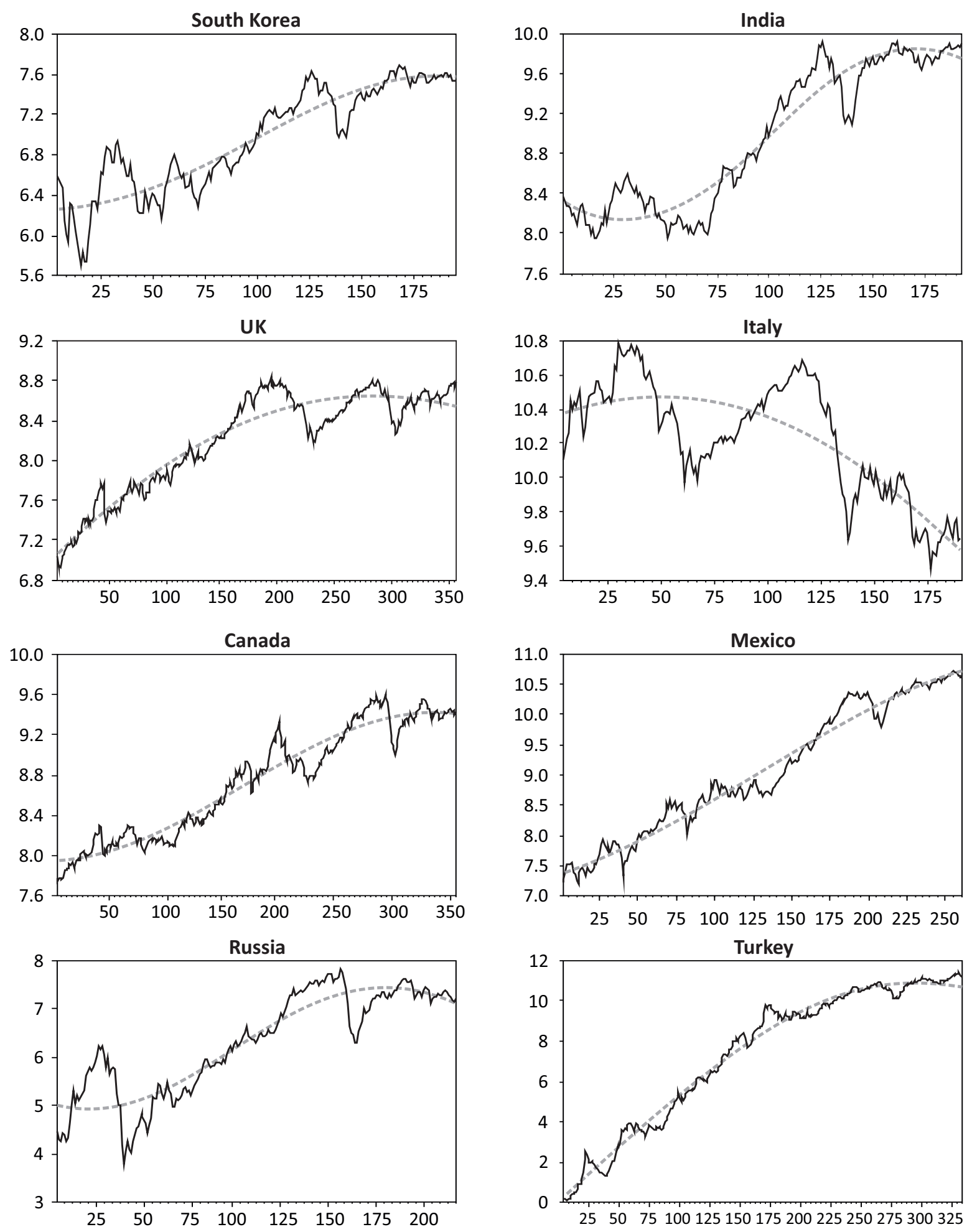

Figure 1 (Continued) Stock Market Index of G-20 Countries and Related Fourier Functions 


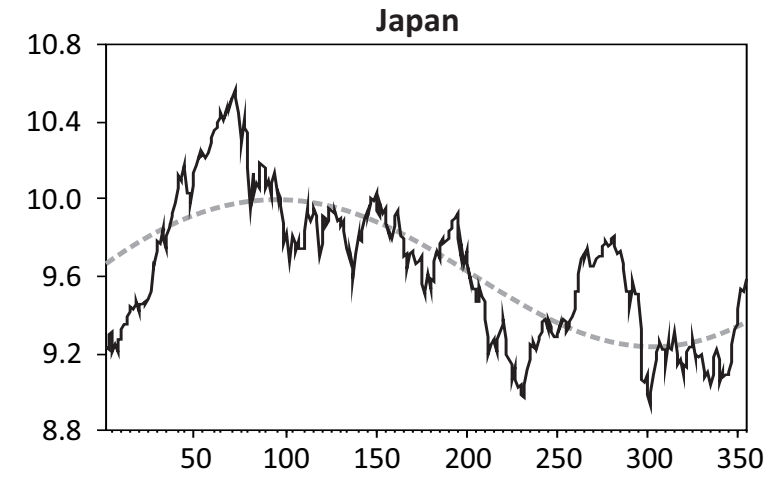

Note: While the lines (-) represent the logarithmic forms of the series, the lines $(--)$ represent the series changed into the Fourier function and thus, the forms applied to the analysis. Moreover, the horizontal and the vertical sections represent the observation number and logarithmic values, respectively.

Figure 1 (Continued) Stock Market Index of G-20 Countries and Related Fourier Functions

Source: Authors

\section{CONCLUSION}

Science is created and developed by a hypothesis and testing the hypothesis. Each one of the hypotheses will be up to date and supported until studies with stronger and more scientific hypotheses and powerful supportive researches into these hypotheses have been carried out. In this context, although the Efficient Market Hypothesis is not supported by striking and powerful studies as once it used to be, it still stands for a significant paradigm in the finance literature. Although the efficient market hypothesis is not up to date, the testing of the existence of the efficient market hypothesis with new techniques is important against the behavioral finance flow.

In this study, the weak-form market efficiency of the exchanges of the G20 countries is tested via the Fourier ADF and the Fourier KSS. As a result of the study, the market efficiency hypothesis is valid for 9 out of the 17 countries and is not valid for the eight of them. Using the technical analysis method may be useful to obtain excessive profits in these eight markets.
In our study, testing weak-form market efficiency, the validity of the efficient market hypothesis is confirmed for Germany, the USA, Argentina, Australia, France, India, the UK, Italy and Japan. It is possible to obtain differentiated, consistent and stable return for these markets. However, this hypothesis is not valid for Brazil, China, Indonesia, South Korea, Canada, Mexico, Russia and Turkey. It is noticed that the efficient market hypothesis is confirmed for countries such as Germany, the USA, Australia, France, UK and Italy, who have developed economies and stock markets as well. This result leads us to finding out that the efficient market hypothesis is more likely to be valid for developed countries. As the supporting findings of our study, M. R. Borges (2008), C. C. Lee et al. (2010), G. Smith and H. J. Ryoo (2003), A. C. Worthington and H. Higgs (2004) and K. P. Narayan (2008) point the existence of a relationship between the development level of countries and weak-form market efficiency.

In this paper, one of the appropriate unit root tests is applied to the time series analysis for each country. Nonetheless, it should not be ignored that there is a strong correlation between the G-20 Stock Markets. Moreover, this correlation may affect the results. Therefore, using the panel root test based on the Fourier function again can provide more advanced and accurate results for further studies. Besides, this paper does not take into account behavioral finance theory, which is an important constraint of the paper.

\section{REFERENCES}

Abraham, A., Seyyed, F., \& Alsakran, S. (2002). Testing the random behavior and efficiency of the gulf stock markets. The Financial Review, 37(3), 469-480. do1: 10.1111/07328516.00008

Anouruo, E., \& Nwala, K. (2014). Unit root properties: Interest rate swaps. Scms Journal of Indian Management, 11(1), 21-32.

Ball, R. (2009). The global financial crisis and the efficient market hypothesis: What have we learned. Journal of Applied Corporate Finance, 21(4), 8-16. do1: 10.1111/j.17456622.2009.00246.x

Basu, S. (1977). Investment performance of common stocks in relation to their price-earnings ratios: A test of the efficient market hypothesis. The Journal of Finance, 32(3), 663-682. do1: 10.1111/j.1540-6261.1977.tb01979.x 
Bayraktar, A. (2012). Etkin piyasalar hipotezi, T. C. Aksaray Üniversitesi İI.B.F. Dergisi, 3(1), 37-46.

Becker, R., Enders, W., \& Lee, J. (2004). A stationarity test in the presence of an unknown number of smooth breaks. Journal of Time Series Analysis, 27(3), 381-409. dol: 10.1111/j.14679892.2006.00478.x

Borges, M. R. (2008). Efficient market hypothesis in european stock markets. The European Journal of Finance, 16(7), 711-726. doi: 10.1080/1351847X.2010.495477

Chaudhuri, K., \& Wu, Y. (2003). Random walk versus breaking trend in stock prices: Evidence from emerging markets. Journal of Banking \& Finance, 27(4), 575-592. doi: 10.1016/ S0378-4266(01)00252-7

Choudhry, T. (1997). Stochastic trends in stock prices: Evidence from Latin American markets. Journal of Macroeconomics, 19(2), 285-304. doi: 10.1016/S0164-0704(97)00016-5

Christopoulos, D. K., \& León-Ledesma, M. A. (2010). Smooth breaks and non-linear mean reversion: Post-Bretton Woods real exchange rates. Journal of International Money and Finance, 29(6), 1076-1093. doi: 10.1016/j.jimonfin.2010.02.003

Çevik, F., \& Yalçın, Y. (2003). İstanbul Menkul Kıymetler Borsası (IMKB) için Zayıf Etkinlik Sınaması: Stokastik birim kök ve kalman filtre yaklaşımı. T. C. Gazi Üniversitesi, İ.̇.B.F. Dergisi, 5(1), 21-36.

Dias, J. C., Lopes, L., Martins, V., \& Benzinho, J. M. (2002). Efficiency tests in the Iberian stock markets. http://ideas. repec.org/p/wpa/wuwpfi/0406001.html

Fama, E. F. (1970). Efficient capital markets: A review of theory and empirical work. The Journal of Finance, 25(2), 383-417 doi: 101111/j.1540-6261.1970.tb00518.x

Fox, J. (2009). The Myth of the Rational Market: A History of Risk, Reward and Delusion on Wall Street. New York: HarperCollins.

Grossman, S. J., \& Stiglitz, J. E. (1980). On the impossibility of informationally efficient markets. The American Economic Review, 70(3), 393-408.

Gujarati, D. (2011). Temel Ekonometri. Çeviren: Ümit Şenesen, Gülay Günlük Şenesen, Literatür Yayıncılık.

Haque, A., Liu, H. C., \& Nisa, F. U. (2011). Testing the weak form efficiency of Pakistani stock market (2000-2010). International Journal of Economics and Financial Issues, 1(4), 153-162.

Hamid, K., Suleman, M. T., Shah, S. Z. A., \& Akash, R. S. I. (2010). Testing the weak form of efficient market hypothesis: Empirical evidence from Asia-Pacific markets. International Research Journal of Finance and Economics, 58, 121-158.
Hasanov, M., \& Omay, T. (2007). Are the transition stock markets efficient? Evidence from non-linear unit root tests. T. C. Central Bank Review, 2, 1-12.

Harvey, D. I., Leybourne, S. J., \& Xiao, B. (2008). A powerful test for linearity when the order of integration is unknown. Regime-Switching Models in Economics and Finance, 12(3), 1-24.

Jensen, M. C. (1978). Some anomalous evidence regarding market efficiency. Journal of Financial Economics, 6(2/3), 95-101. doi: 10.1016/0304-405X(78)90025-9

Kapetanios, G., Shin, Y., \& Snell, A. (2003). Testing for a unit root in the nonlinear STAR framework. Journal of Econometrics, 112(2), 359-379. doi: 10.1016/S0304-4076(02)00202-6

Kawakatsu, H., \& Morey, M. (1999). An empirical examination of financial liberalization and the efficiency of emerging market stock prices. Journal of Financial Research, 22(4), 355411.

Lee, C. C., Lee, J., \& Lee, C. (2010). Stock prices and the efficient market hypothesis: Evidence from a panel stationary test with structural breaks. Japan and the World Economy, 22(1), 49-58. doi: 10.1016/j.japwor.2009.04.002

Lean, H. H., \& Smyth, R. (2007). Do Asian stock markets follow a random walk? Evidence from LM unit root tests with one and two structural breaks. Review of Pacific Basin Financial Markets and Policies, 10(1), 15-31. do1: 10.1142/ S0219091507000933

Malkiel, B. G. (2003). The efficient market hypothesis and its critics. The Journal of Economic Perspectives, 17(1), 59-82. do1: 10.1257/089533003321164958

Malkiel, B. G. (2005). Reflections on the efficient market hypothesis: 30 years later. The Financial Review, 40(1), 1-9. do1: 10.1111/j.0732-8516.2005.00090.x

Narayan, K. P. (2008). Do shocks to G7 stock prices have a permanent effect? Evidence from panel unit root tests with structural change. Mathematics and Computers in Simulation, 77(4), 369-373. doi: 10.1016/j.matcom.2007.03.003

Narayan, K. P., \& Prasad, A. (2007). Mean reversion in stock prices: new evidence from panel unit root tests for seventeen European countries. Economics Bulletin, 3(34), 1-6.

Narayan, K. P., \& Smyth, R. (2007). Mean reversion versus random walk in $\mathrm{G} 7$ stock prices evidence from multiple trend break unit root tests. International Financial Markets, Instutions and Money, 17(2), 152-166. doi: 10.1016/j.intfin.2005.10.002

Smith, G., \& Ryoo, H. J. (2003). Variance ratio tests of the random walk hypothesis for European emerging stock 
markets. The European Journal of Finance, 9(3), 290-300. doi/ abs/10.1080/1351847021000025777

Sewell, M. (2011). History of the Efficient Market Hypothesis. Research Note 11/04, UCL Department of Computer Science.

Tarı, R., (2012). Ekonometri. Umutttepe Yayınları, Kocaeli

Timmermann, A., \& Granger, C. W. J. (2004). Efficient market hypothesis and forecasting. International Journal of Forecasting, 20(1), 15-27. doi: 10.1016/S0169-2070(03)00012-8

Worthington, A. C., \& Higgs, H. (2004). Random walks and market efficiency in European equity markets. Global Journal of Finance and Economics, 1(1), 59-78.
Yllanc1, V., \& Eriş, Z. A., (2013). Purchasing power parity in African countries: Further evidence from fourier unit root tests based on linear and nonlinear models. South African Journal of Economics, 81(1), 20-34. dor: 10.1111/j.18136982.2012.01326.x

Zeren, F., \& Konuk, F. (2013). Testing the random walk hypothesis for emerging markets: evidence from linear and non-linear unit root tests. Romanian Economic and Business Review, 8(4), 61-71.

Zhou, S., \& Kutan, A.M. (2014). Smooth structural breaks and the stationarity of the yen real exchange rates. Applied Economics, 46(10), 1150-1159. do1: 10.1080/00036846.2013.868587

www.uk.finance.yahoo.com

$$
\begin{array}{r}
\text { Received on 20 } 0^{\text {th }} \text { October 2014, } \\
\text { after revision, } \\
\text { accepted for publication on } 15^{\text {th }} \text { December } 2014 . \\
\text { Published online on } 22^{\text {nd }} \text { December } 2014
\end{array}
$$

Fatih Burak Gümüş is an Assistant Professor at the Faculty of Management, Sakarya University, Sakarya, Turkey. He obtained his $\mathrm{PhD}$ in finance. His scientific interests are focuesed on behavioral finance, insurance and the real-estate sector. He is the author and co-author of many papers published in scientific journals and at congresses.

Feyyaz Zeren is a Research Assistant at the Faculty of Economics and Administrative Sciences, Namik Kemal University, Tekirdağ, Turkey. He received his $\mathrm{PhD}$ in finance. The key areas of his scientific interesting are finance, time series and the panel data analysis. 


\title{
ANALIZA HIPOTEZE O EFIKASNOM TRŽIŠTU UZ POMOĆ FOURIER TESTOVA JEDINIČNOG KORENA: DOKAZ ZA ZEMLJE G-20
}

\author{
Fatih Burak Gümüş ${ }^{a}$, Feyyaz Zeren ${ }^{b}$ \\ ${ }^{a}$ Fakultet za menadžment, Sakarya Univerzitet, Sakarya, Turkey \\ ${ }^{b}$ Fakultet ekonomije i poslovnih nauka, Namık Kemal Univerzitet, Tekirdağ, Turkey
}

\begin{abstract}
Hipoteza o efikasnom tržištu predstavlja jednu od najvažnijih teorija u finansijama, i jednu od najznačajnijih istraživačkih oblasti za razvijene, i za berze u razvoju. U radu je testirana Hipoteza o slučajnom hodu za glavne berze u zemljama G-20. Pre svega, određena je linearnost serija. Šesnaest od sedamnaest berzi ima linearnu strukturu; stoga je, na te serije primenjen Fourier ADF test jediničnog korena, koji koristi trigonometrijske funkcije s ciljem određivanja odstupanja većih od proseka zavisne varijable, i koji uzima u obzir višestruke strukturne prekide. Uz to, za berzu Japana, kao jedinu berzu sa nelinearnom strukturom, upotrebljen je Fourier KSS test jediničnog korena, koji poseduje iste funkcije kao Fourier ADF test jediničnog korena. Rezultat izvršenih istraživanja ukazuje na to da se berze devet zemalja očituju kao efektivne u slaboj formi, a za preostalih osam zemalja odnosna hipoteza nije validna.
\end{abstract}

Ključne reči: Hipoteza o efikasnom tržištu, slučajan hod, međunarodna finansijska tržišta, Test linearnosti, Fourier testovi jediničnog korena

JEL Classification: G14, G15 